\title{
EARLY PALAEOZOIC HADIMOPANELLIDS OF ESTONIA AND KIRGIZIA (USSR)
}

The phosphatic microremains of problematic Cambrian fossil, Hadimopanella, were first described by I. Gedik (1977) from Turkey. Since this time the number of species of this genus has increased (Bengtson, 1977; Gedik, 1981; Wrona, 1982; van den Boogaard, 1983; Peel, Larsen, 1984; Berg-Madsen, 1985) and the distribution area of the genus considerably widened (text-figs 1 and 2). However, the structure of the skeletal elements, sclerites, of this animal, and, particularly its systematic position which is unclear so far need the further study. Due to morphological diversity of sclerites, the established species may be of some help in the subdivision and correlation of the Cambrian deposits. All the previously recorded specimens of Hadimopanella come of carbonate deposits, limestones and dolomites.

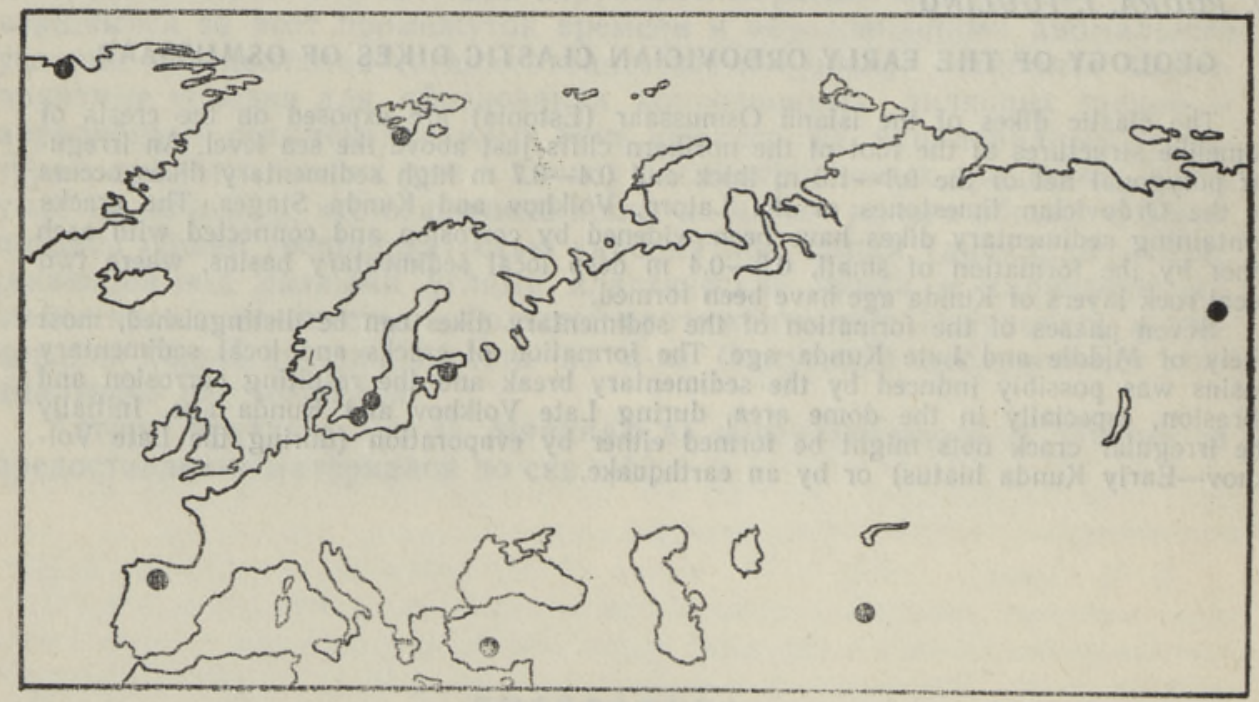

Text-fig. 1. Location map of hadimopanellids (see also text-fig. 2).

Text-fig. 2. Distribution of the Early Palaeozoic hadimopanellids. In the upper part of the drawing there has been given the distribution of sclerites in the Cambrian and Ordovician boundary beds of the Turjekelder outcrop (see also Kaljo et al., 1986). 1 - kerogen-bearing argillite, 2 - claystone, $3-$ sandstone, $4-$ silty sandstone, 5 - siltstone, $6-$ discontinuity surface, $7-$ shells of inarticulate brachiopods, $8-$ detrite of shells, $9-17-$ the numbers of beds, $\mathrm{H}$ and $\mathrm{K}-$ the finds of Hadimopanella collaris sp. n. and Kaimenella reticulata gen. n. sp. n. in section. The scale 1:50. 


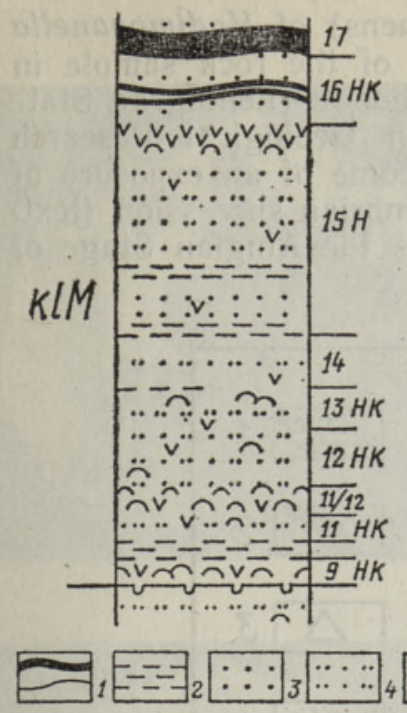

चี 6 ก 7 V 8 HK

\section{Kaimenella}

reticulata n. gen. n.sp.

(PI.II, fig. 2)

$\times 227$

Hadimopanella collaris n.sp. (PI.II, fig. 1)

$\times 252$

\section{TUTKEY}

(Gedik, 1977, pl. Y, fig. 1b)

$\times 212$
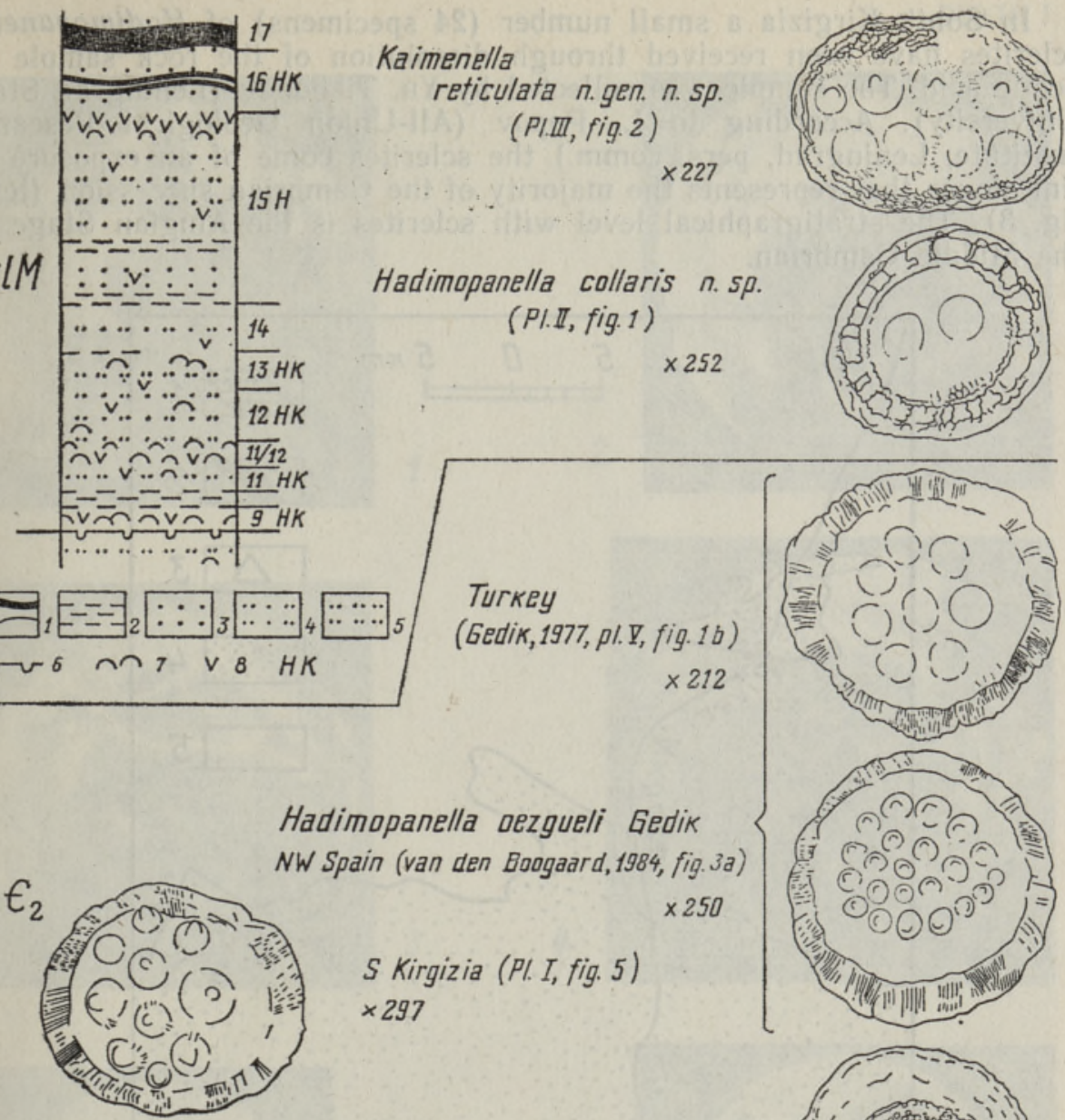

Hadimopanella aezgueli Gedik

NW Spain (van den Boogaard, 1984, fig. 3a)

Hadimopanella sp.

S Baltascandia (Berg-Madsen, 1985, fig. 3A)

$\times 450$

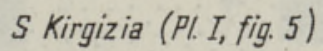

$\times 297$

$\times 250$

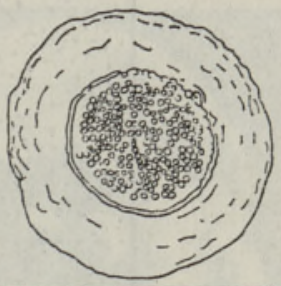

SS Spitsbergen (Wrana, 1982, pl. 2, fig 4a)

$\times 234$

Hadimopanella

apicata Wrana

$\epsilon_{1}$

$N$ Greenland (Pee/ \& Larsen, 1984, fig. $2 \mathrm{H}$ )

$\times 3017$

Hadimopanella knappologica (Bengtson) Siberian Platform (Bengtsan, 1977, fig. 2)
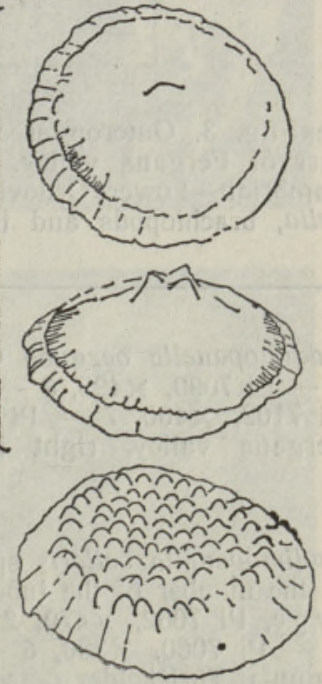
In South Kirgizia a small number (24 specimens) of Hadimopanella sclerites have been received through dissolution of the rock sample in acetic acid. The sample was collected by Yu. Tikhonov (Leningrad State University). According to L. Popov (All-Union Geological Research Institute, Leningrad, pers. comm.) the sclerites come of an exposure of limestones that represents the majority of the Cambrian succession (textfig. 3). The stratigraphical level with sclerites is the Amgian Stage of the Middle Cambrian.

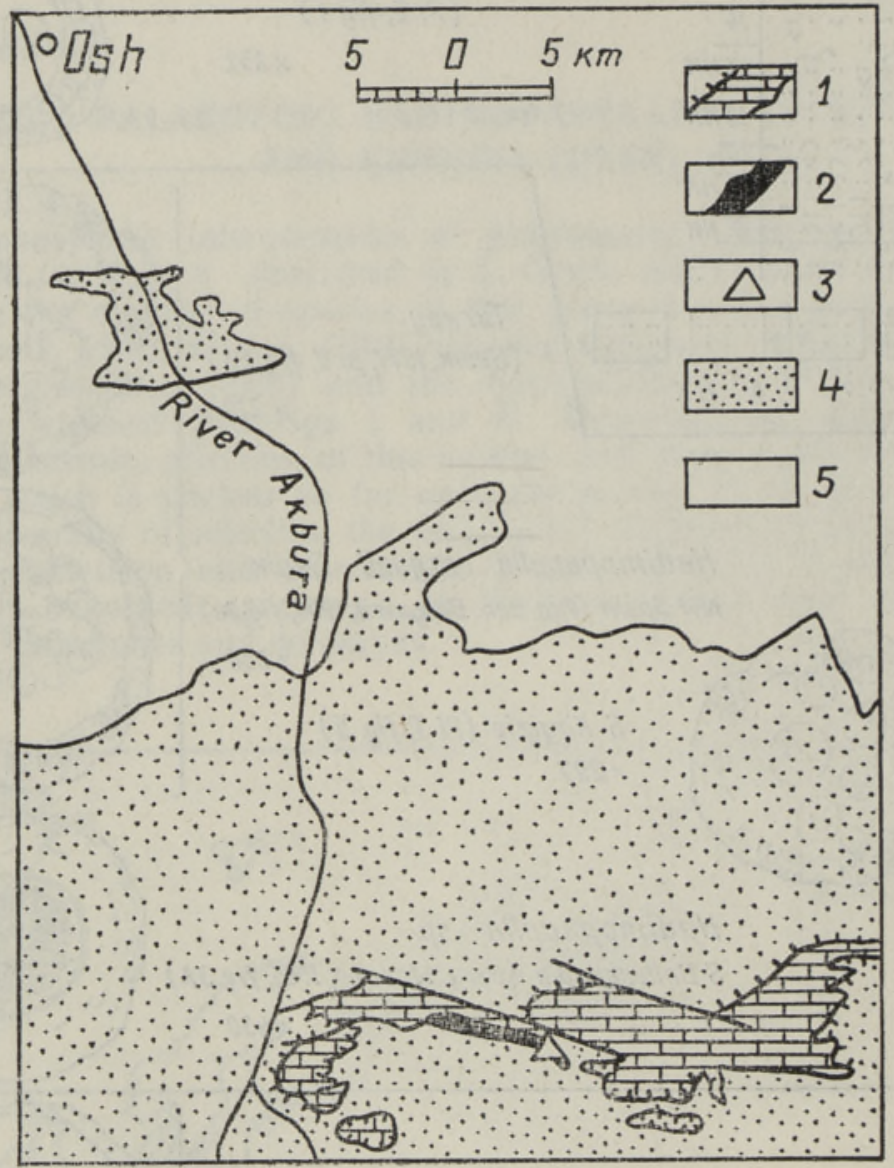

Text-fig. 3. Outcrop area of the Hadimopanella oezgueli Gedik in South Kirgizia, SE part of Fergana valley. 1 - Silurian-Lower carboniferous limestone deposits, $2-$ Cambrian-Lower Ordovician limestone deposits, 3 - locality of Cambrian Hadimopanella, brachiopods and trilobites, 4 - different Palaeozoic rocks, $5-$ Mesozoic and Kainozoic rocks.

\section{PLATE I}

Hadimopanella oezgueli Gedik. SEM micrographs of the sclerites $1-\mathrm{Pi} 7101, \times 690$, $2-\mathrm{Pi} 7099, \times 495,3-\mathrm{Pi} 7096, \times 470,4-\mathrm{Pi} 7103, \times 470,5-\mathrm{Pi} 7104, \times 440,6-$ Pi $7102, \times 400,7-\mathrm{Pi} 7107, \times 500,8-\mathrm{Pi} 7098, \times 445$, South Kirgizia, SE part of Fergana valley, right bank of Chalkuiriuk stream, Sulutor hill, Middle Cambrian, Amgian Stage.

\section{PLATE II}

Hadimopanella collaris sp. n. SEM micrographs of the sclerites showing the variability of the number of the tubercles and the ornamentation of the marginal brim. $1-\mathrm{holo}$. ty pe, Pi 7062, $\times 470,2-\mathrm{Pi} 7058, \times 625,3-\mathrm{Pi} 7051, \times 455,4-\mathrm{Pi} 7057, \times 525$, $5-\mathrm{Pi} 7060, \times 380,6-\mathrm{Pi} 7059, \times 810,7-\mathrm{Pi} 7065, \times 450,8-\mathrm{Pi} 7067, \times 590$, Estonia, Turjekelder outcrop, Cambrian and Ordovician boundary beds, Kallavere Forma. tion, Maardu Member. 
PLATE I
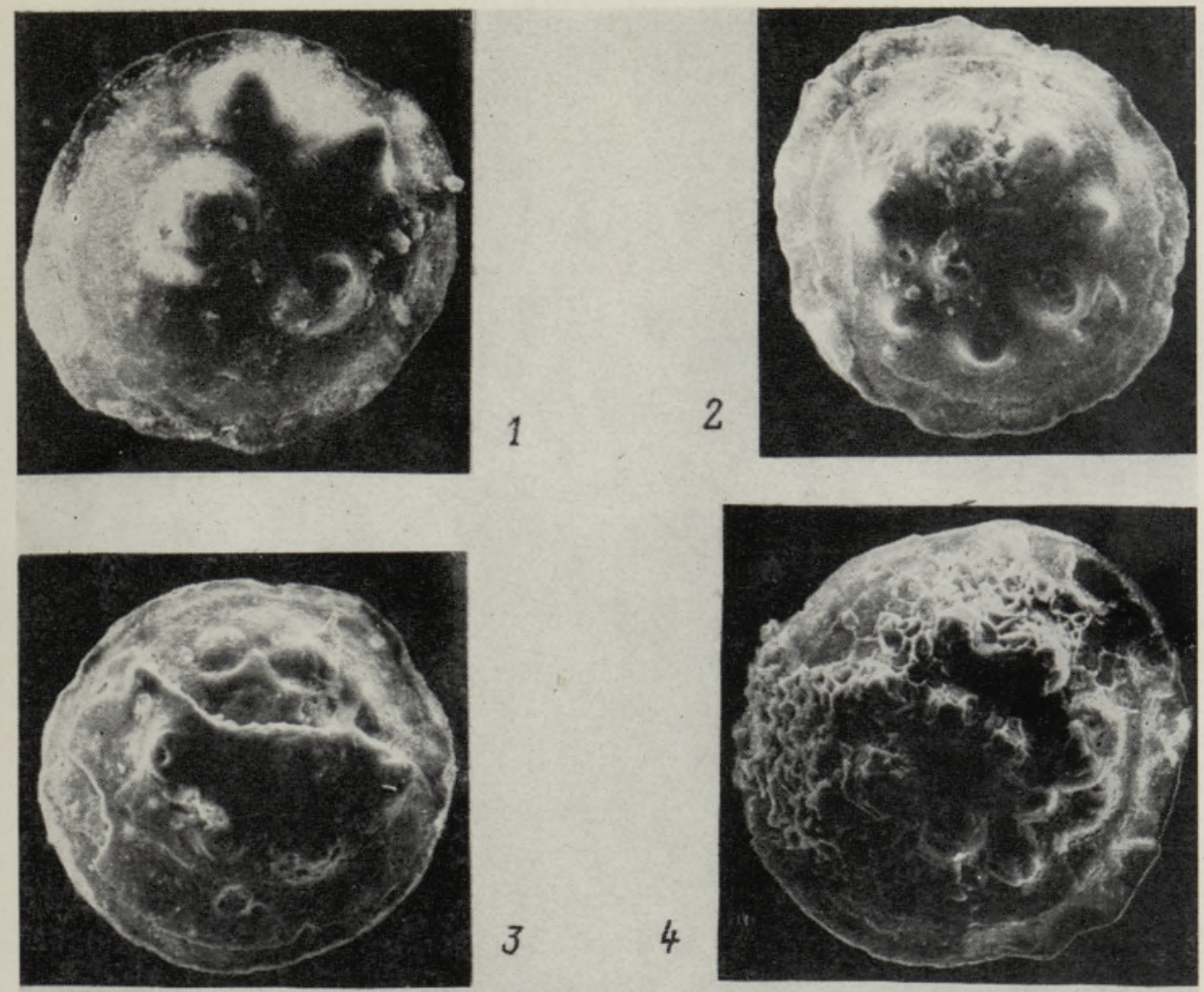

3
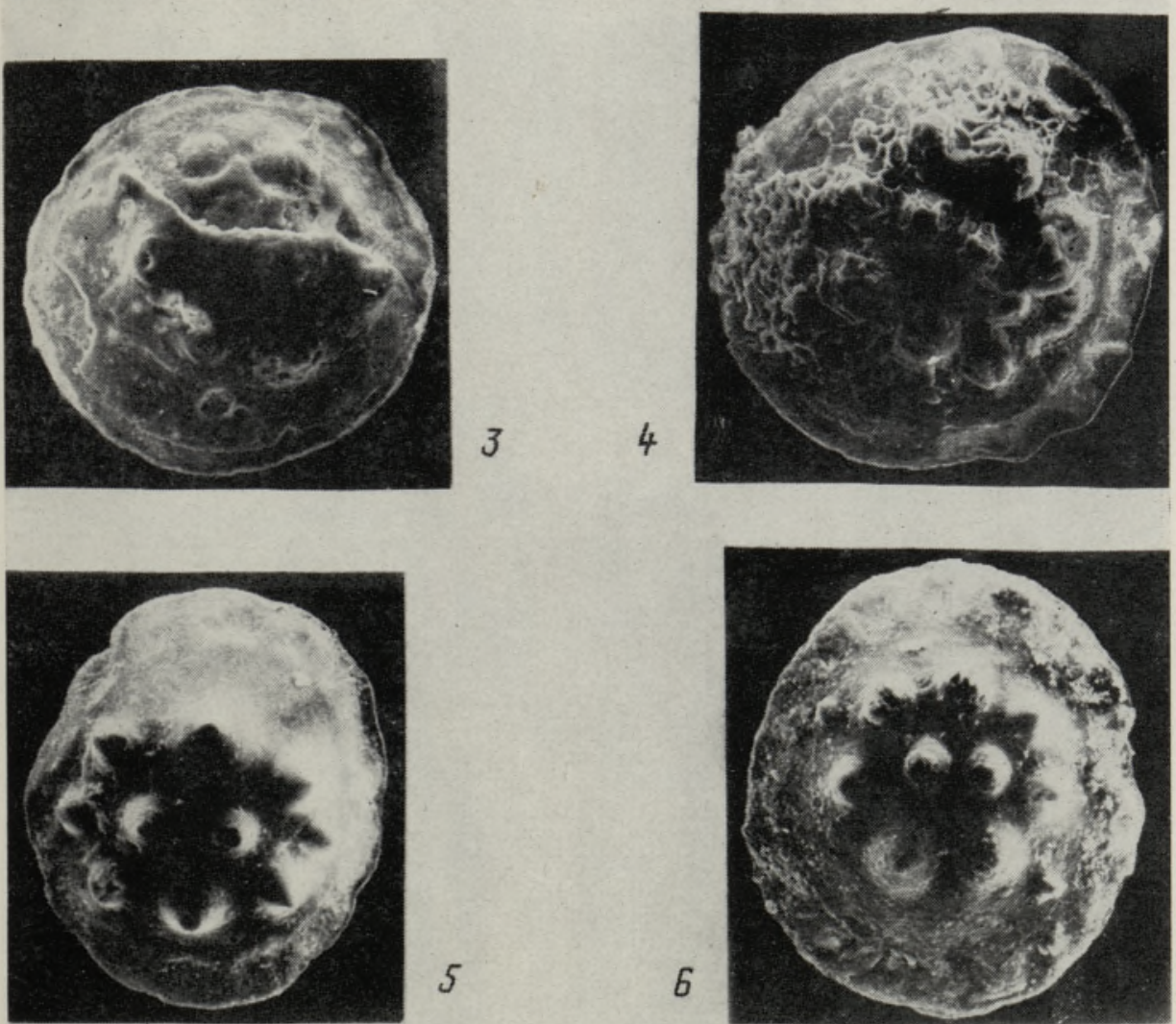

5
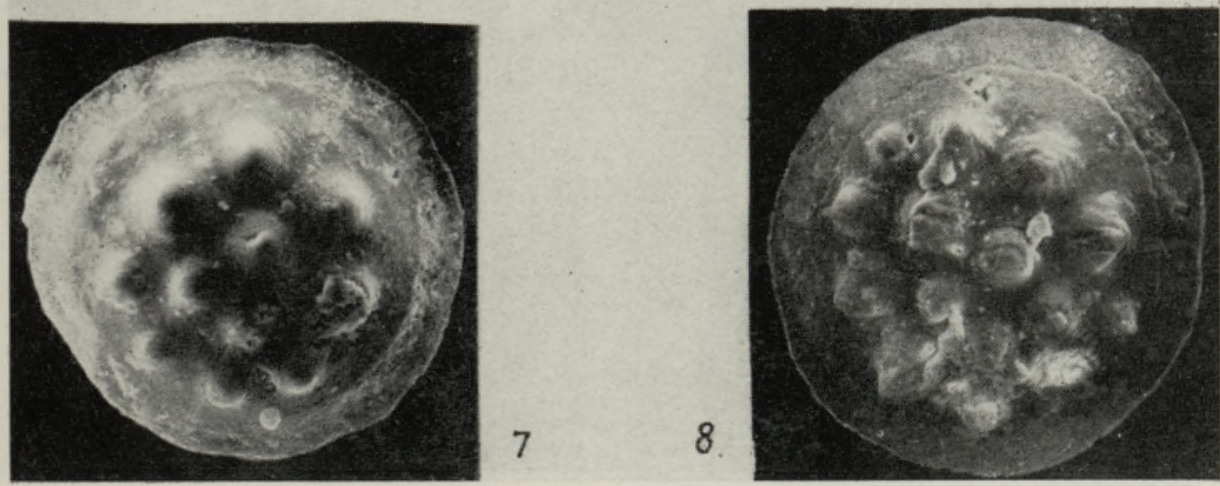

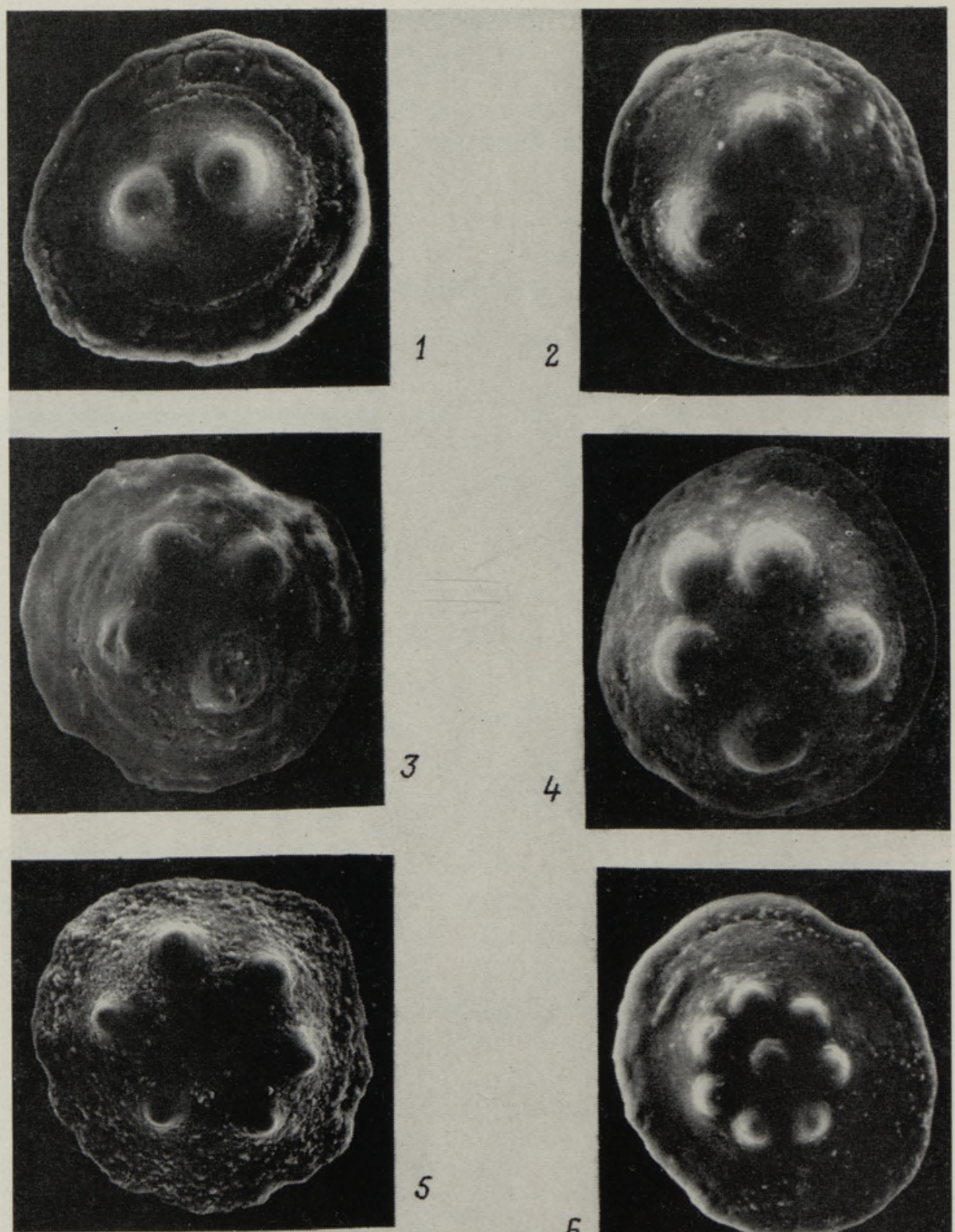

5
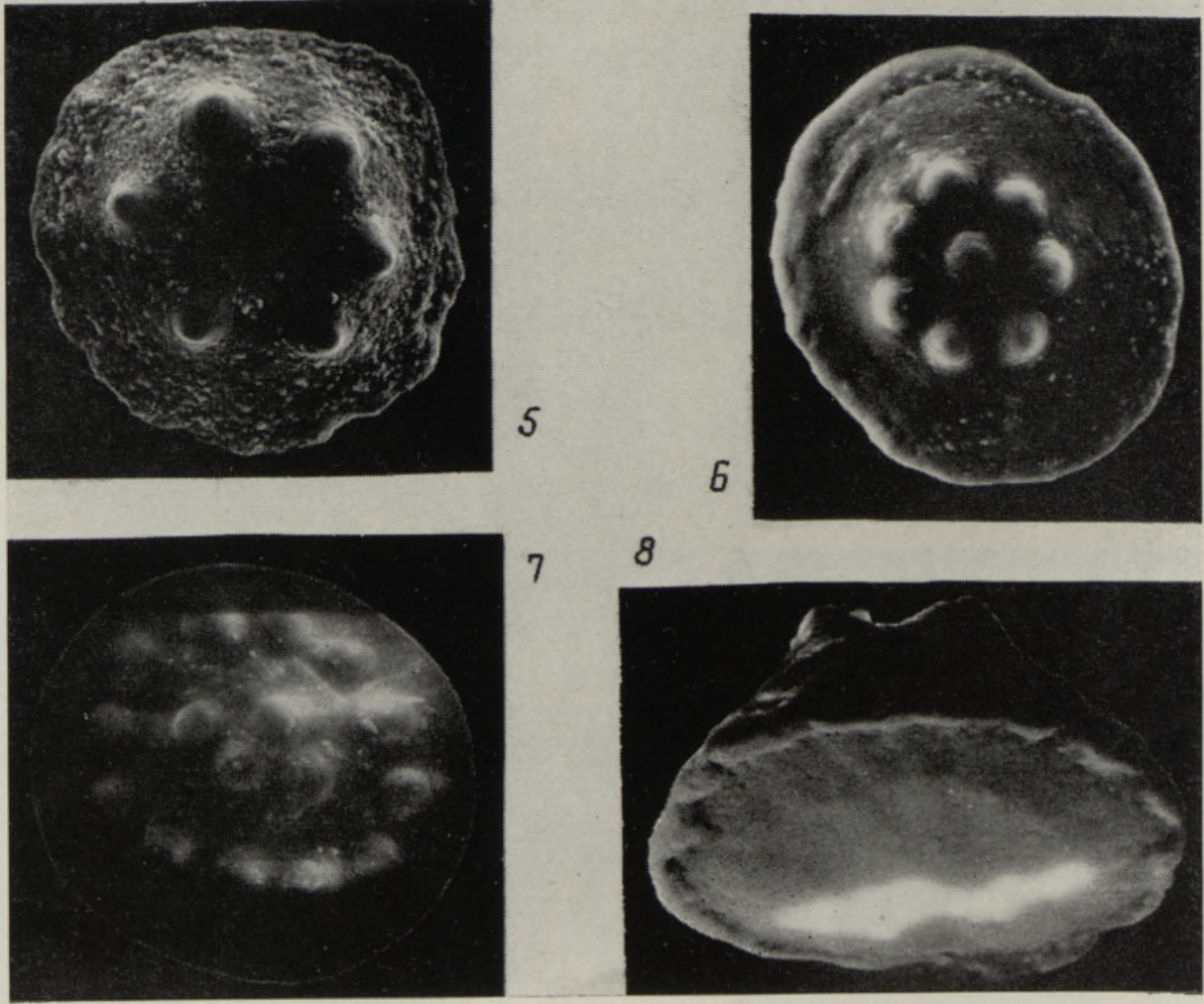

78

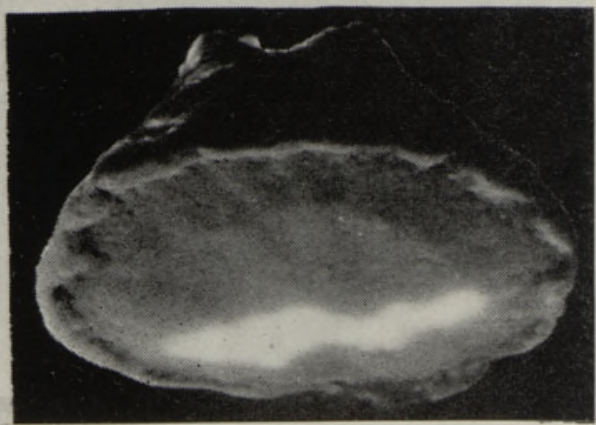



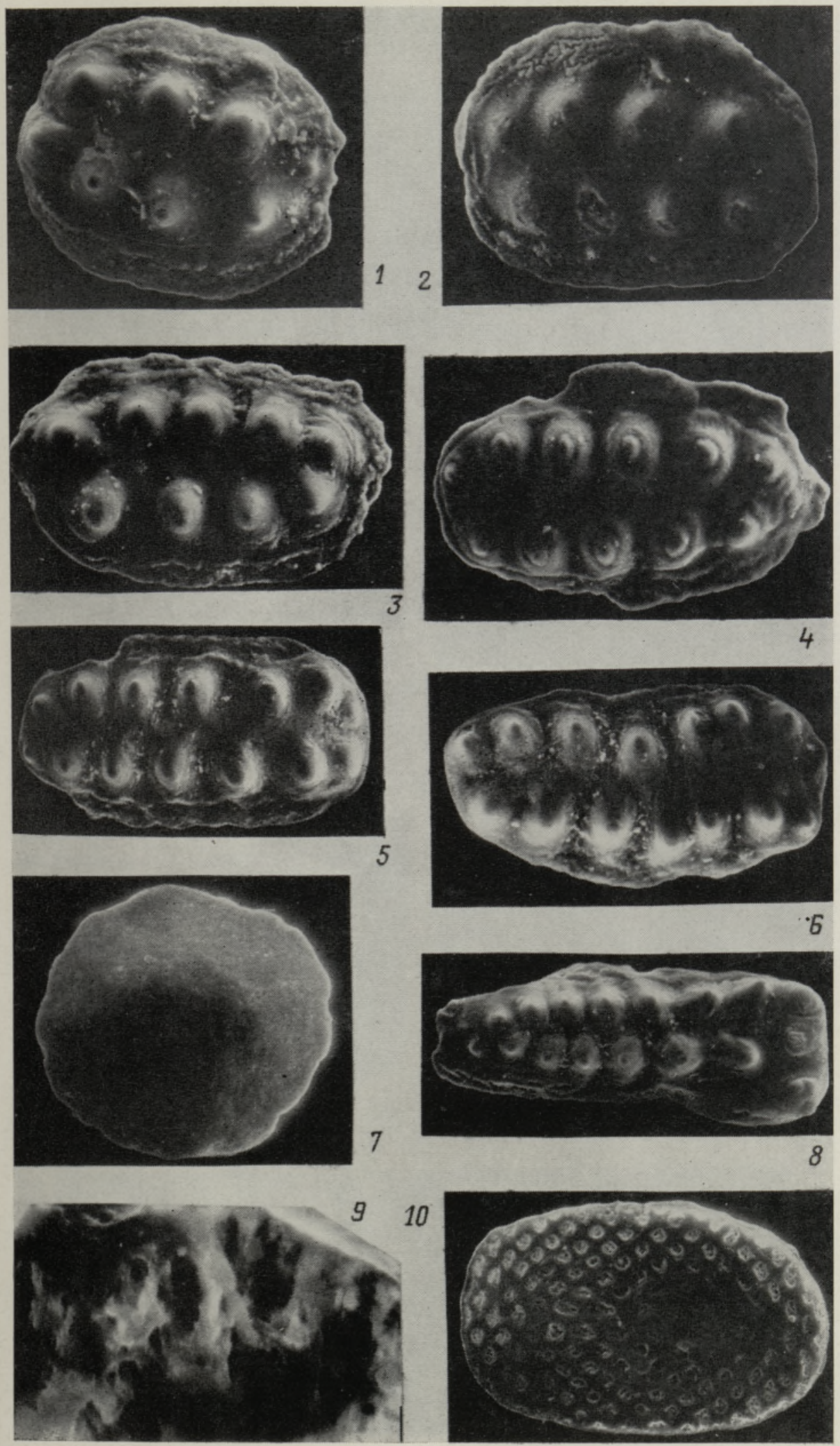

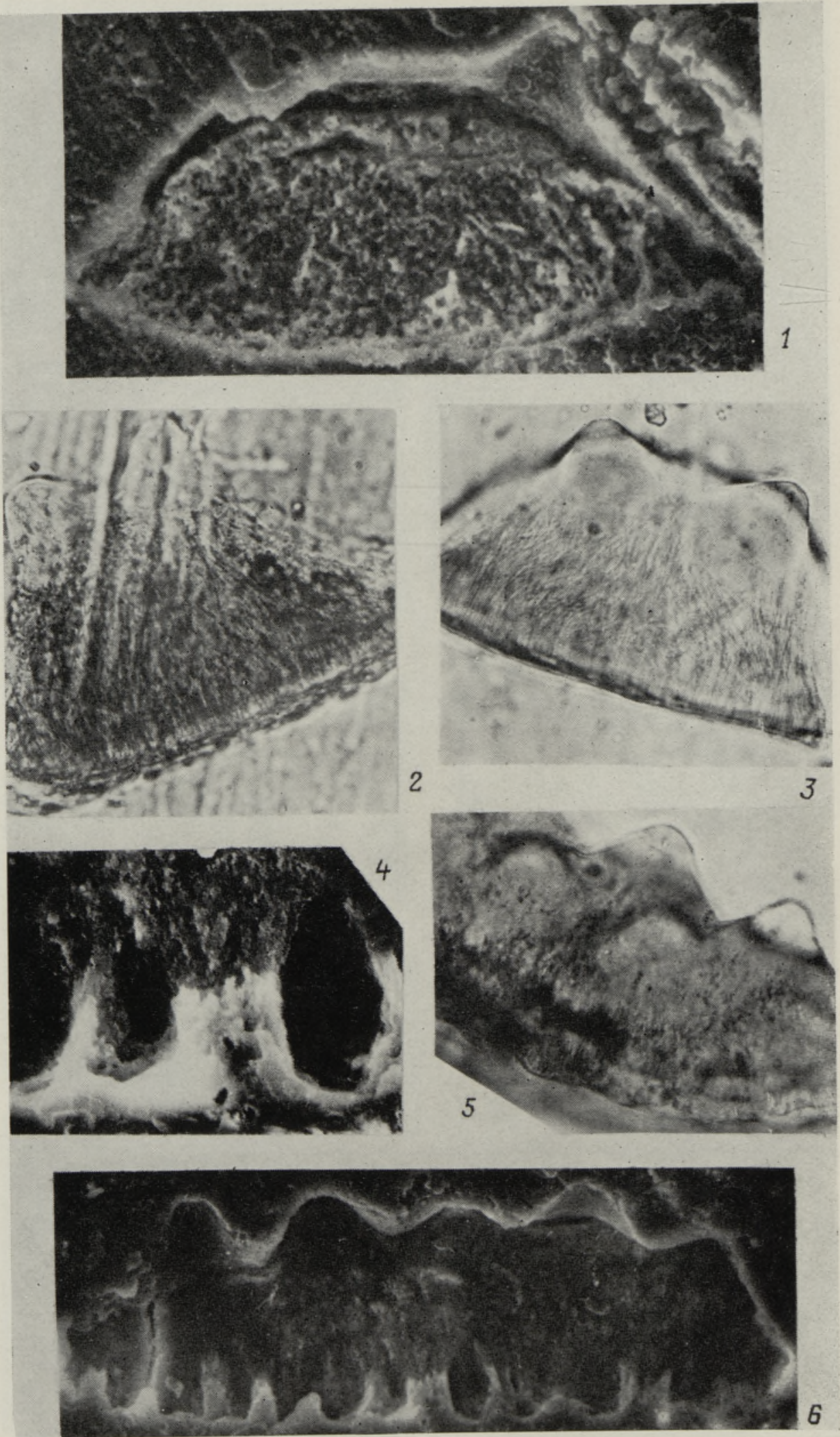
In Estonia phosphatic sclerites (about 280 specimens) of a very different morphology and microstructure were discovered by K. Mens (Institute of Geology, Tallinn) in samples of the Turjekelder outcrop in North Estonia. This section is represented by terrigenous rocks of the Upper Cambrian Ulgase and Kallavere Formations. The latter includes also a part of the Lower Ordovician (for location map, lithology and stratigraphical discussion see Kaljo et al., 1986). Sclerites have been recorded from the lower part of the Kallavere Formation in the Maardu Member below the first level with eoconodonts Eoconodontus notchpeakensis and Cordylodus andresi, occurring in siltstones and sandstones, but being completely absent in claystones.

The samples of terrigenous rocks have not been dissolved in any acid. The weakly cemented sandstones and siltstones were sieved and sclerites were picked out from different fractions. The diameter of these skeletal elements mostly ranges from $0.1-0.05 \mathrm{~mm}$, in some cases exceeding $0.1 \mathrm{~mm}$. Sclerites of two different morphotypes were found: circular and strongly elongated, with rather great variations in the number and arrangement of tubercles, in the sculpture of the marginal brim, the nature of the visceral surface of the base and the internal structure of sclerites. On the basis of these differences both Hadimopanella and a new genus, Kaimenella were distinguished.

The histology of the vertical thin sections of the sclerites was studied in two ways: 1) investigating the unetched specimens under the light microscope, and 2) observing the polished and etched (with $1 \% \mathrm{HCl}$ during $20-30$ secs) sclerites under the SEM.

The author agrees with S. Bengtson (1977) and R. Wrona (1982) that the elements were external dermal sclerites of a problematic animal. They were attached to soft tissues to the extent of the marginal brim whereas the tuberculated area remained out of these tissues. In Hadimopanella fine sparse pores have been found on the visceral surface of the sclerites. The visceral surface of elongated Kaimenella sclerites differs from that of Hadimopanella ones. It is penetrated by relatively large pores arranged in a very regular pattern, thus resembling the Middle Ordovician problematic fossil Milaculum ethinclarci Müller from South Ontario (Müller, 1973, Taf. 34, Fig. $8 a, b)$.

Though the sclerites reveal some common characters with the skeletal elements of the early vertebrates, i. e. agnathans, their origin remains problematical at present. The sclerites of Hadimopanella resemble in their three-layered microstructure, in the presence of canals (fine tubules of fibres) and their arrangement the remains of some heterostracans on the

\section{PLATE III}

Kaimenella reticulata gen. n. sp. n. SEM micrographs of the sclerites: $1-6,8-$ showing the variability of the shape of sclerites and the number of the tubercles, $9-$ spongy middle layer of sclerite, 10 - visceral surface of sclerite.

Hadimopanella collaris sp. n. 7 - visceral surface of the sclerite.

1 - Pi $7061, \times 430,2-$ holoty pe, Pi $7052, \times 420,3-\mathrm{Pi} 7063, \times 510,4-\mathrm{Pi} 7056$, $\times 510,5-\mathrm{Pi} 7054, \times 320,6-\mathrm{Pi} 7055, \times 380,7-\mathrm{Pi} 7066, \times 410,8 \mathrm{Pi} 7053, \times 270$, $9-\mathrm{Pi} 7077, \times 3000,10-\mathrm{Pi} 7064, \times 350$, Estonia, Turjekelder outcrop, Cambrian and Ordovician boundary beds, Kallavere Formation, Maardu Member.

\section{PLATE IV}

Vertical thin sections of sclerites. 1-3. Hadimopanella collaris sp. n. 1 - polished and etched cross section of sclerite under the SEM, 2, 3- polished cross sections of sclerites under the light microscope. 4-6-Kaimenella reticulata gen. n. sp. n. 4, 6- polished and etched cross section of sclerite under the SEM, 5- polished cross section of sclerite under the light microscope. $1-\mathrm{Pi} 7068, \times 900,2-\mathrm{Pi} 7071, \times 750,3-\mathrm{Pi} 7070$, $\times 700,4,6-\mathrm{Pi} 7075, \times 2100, \times 780,5-\mathrm{Pi} 7076, \times 700$. 
one hand and these of anaspids on the other. The spongy internal structure of Kaimenella sclerites may be considered as being close to that of some heterostracans. In a number of Heterostraci including the early representative (Astraspis), the middle layer of skeletal elements consists of the spongy tissue. Rather large pores in the basal layer similar to these of Kaimenella are also known in the scales of early fishes, e. g. in Poracanthodes and Tylodus.

The terminology of S. Bengtson (1977) and R. Wrona (1982) is used with some supplements.

The specimens with indexes $\mathrm{Pi}$ are housed at the Institute of Geology, Academy of Sciences of the Estonian SSR.

I am indebted to K. Mens (Tallinn), L. Popov and Yu. Tikhonov (Leningrad) for making available the microfossils and for helpful discussions. I thank E. Kurik for examining and improving the manuscript. I am obliged to $\mathrm{K}$. Tarassova (Institute of Experimental Biology, Tallinn) for the photographs of light microscope, U. Moldov for taking the SEM micrographs. I acknowledge A. Noor for linguistic help and L. Lippert for drawings.

\section{Description}

Phylum, class and order - incertae sedis

Hadimopanellidae fam. $n$.

Diagnosis. Problematic animal with circular to elongated phosphatic sclerites, the latter ones covered on the external surface with tubercles, and having marginal brim. Visceral surface pierced by sparse pores.

\section{Genus Hadimopanella Gedik, 1977}

Type species. Hadimopanella oezgueli Gedik, 1977.

Diagnosis. Small phosphatic sclerites with circular to slightly oval outline. The external surface conical with a flat crest and covered with minute tubercles. The number of tubercles ranges from 2 to 30 . The visceral surface of the base smooth. Internal structure three-layered, consisting of base, core and cap. Fine canals (tubules) of the core rise independently from the base.

Species content. Hadimopanella oezgueli Gedik, 1977, H. knappologica (Bengtson), 1977, H. apicata Wrona, 1982, Hadimopanella sp. Berg-Madsen, 1985, Hadimopanella collaris n. sp.

Hadimopanella oezgueli Gedik, 1977

Pl. I, figs. $1-8$

Diagnosis. Phosphatic sclerites circular to slightly oval. The tubercles on the external surface ( 4 to 30 in number) vary in size. The marginal brim radially finely striated.

Distribution. Middle Cambrian of Taurids in Turkey, the Lancara Formation in NW Spain, Amgian Stage of South Kirgizia.

Material and locality. 24 sclerites of variable degree of preservation; South Kirgizia, SE part of Fergana valley, right bank of Chalkuiriuk stream, Sulutor hill.

Description. Morphology. The sclerites in our material have mostly irregular circular outline (Pl. I, figs. $1-8)$, some of them being also oblong (Pl. I, figs. 5,6$)$. The greatest diameter is $0.12 \mathrm{~mm}$. The slightly raised 
external surface is covered with 4 to 12 conical tubercles. Like the material from NW Spain (van den Boogaard, 1983, Figs. 3 and 4), the tubercles on a sclerite vary in size, the smaller ones generally being placed marginally (Pl. I, figs. 2, 6-8). The outermost tubercles may be arranged in a circle (P1. I, figs. 2, 7, 8) or in a oval (Pl. I, figs. 5, 6) enclosing in the middle $1-2$ or more tubercles. In elongated sclerites between the tuberculated area and marginal brim there remains a wider smooth surface (Pl. I, figs. 5-7). The downstepped marginal brim bears fine radial striae (P1. I, figs. 1, 2, 5). Some specimens have «scratches» (P1. I, figs. 1,8$)$. The visceral surface is smooth, slightly convex to concave. Histology has not been studied.

Associated fauna. Chancelloria sp., Micromitra sp., Linnarssonia sp.

\section{Hadimopanella collaris sp. $\mathrm{n}$.}

\section{Pl. II, figs. $1-8$, Pl. III, fig. 7 , Pl. IV, figs. $1-3$}

Derivation of name: collar, to call attention to the sculpture of the marginal brim.

Holotype and type locality. Pi 7062 (Pl. II, fig. 1), Estonia, Turjekelder outcrop, Cambrian and Ordovician boundary beds, Kallavere Formation, Maardu Member.

Material. About 250 specimens.

Diagnosis. Sclerites circular and covered with tubercles of uniform size. The number of tubercles varies from 2 to 16 . Marginal brim with a mosaic pattern. The brim curves down bordering the base.

Description. Morphology. Sclerites are somewhat irregularly circular in outline (Pl. II, figs. 1-7, Pl. III, fig. 7). The diameter of sclerites is predominantly $0.05-0.1 \mathrm{~mm}$. The external surface («nodular surface» after S. Bengtson, 1977; «outer/upper side» after R. Wrona, 1982) is smooth and conical (P1. II, fig. 8). The marginal area of the external surface shows fine radial striae (Pl. II, fig. 1). The central part of this surface bears 2 to 16 smooth convex or conical tubercles (Pl. II, figs. $1-7)$, rather even in size. Depending on their number, the tubercles tend to be arranged in circles, but sometimes one of them is placed irregularly (Pl. II, figs. 3, 4). Some tubercles on their worn surface show the pores (P1. II, fig. 4). The marginal brim is separated from the external surface with $1-2$ rows of the pores (Pl. II, figs. $2-4,6)$ or shallow grooves. The marginal brim has a mosaic pattern (P1. II, fig. 1), which is usually abraded. The external surface and the marginal brim of the sclerite on Pl. II, fig. 5 seems to be recrystallised. The marginal brim curves down bordering the base (Pl. II, fig. 8). The visceral surface with pores is smooth, may be slightly convex (Pl. III, fig. 7), flat or concave.

Histology. The internal structure of Hadimopanella collaris sp. n. can be observed better in unetched thin sections (P1. IV, figs. 2, 3). Three layers can be distinguished: 1) lamellar basal layer (base), 2) middle «fibrous» layer (core), and 3) transparent almost homogeneous enamel-like layer (cap). The base is very thin and lamellar composed of $4-5$ lamellae (Pl. IV, figs. 2, 3), and penetrated with sparse pores (Pl. III, fig. 7). Lamellar base was not visible (or not preserved?) in etched specimens ( $\mathrm{Pl}$. IV, fig. 1). «Fibrous» core («core» by S. Bengtson, «basal core» by R. Wrona) forms the major part of the sclerite. At present it remains unclear whether the fine canals of the core are either the canals through which metabolism of the sclerites took place, or they' represent fine tubules housing the organic fibres (Sharpey's fibres) which served for attachment of the sclerites to skin. The fine canals or tubules seem to start already from the lower part of the lamellar base and are directed up towards the middle 
portion of the sclerites. Single canals or tubules of fibres are present also in the tubercles. The latter ones are still of a more homogeneous composition. The external surface of the sclerite is covered with a transparent layer, called «capping» by S. Bengtson and «hyaline cap» by R. Wrona. This layer is less subjected to $\mathrm{HCl}$ (Pl. IV, fig. 1).

Comparison. Hadimopanella collaris sp. n. differs from $H$. oezgueli, $H$. knappologica and $H$. apicata in having mosaic pattern and concentric furrows on the marginal brim. On the latter area radial fine striae or folds are present in $H$. oezgueli and $H$. apicata, respectively. The number of tubercles in $H$. collaris sp. $\mathrm{n}$. is larger than in $H$. apicata, about the same as in H. oezgueli, but smaller than in H. knappologica or in Hadimopanella sp. from South Baltoscandia.

Associated fauna. Phakelodus tenuis (Müller), Furnishina cf. furnishi Müller, Prooneotodus cf. gallatini (Müller), Westergaardodina cf. bicuspidata Müller, Muellerodus sp., Schmidtites celatus (Mickwitz), Ungula ingrica (Eichwald).

\section{Genus Kaimenella gen. n.}

Derivation of name. After Dr. Kaisa Mens, who discovered the first hadimopanellids in Estonia.

Type and only species. Kaimenella reticulata sp. n., Estonia, Turjekelder outcrop, Cambrian and Ordovician boundary beds, Kallavere Formation, Maardu Member.

Diagnosis. Phosphatic sclerites elongated. On the external surface two subparallel rows of tubercles. The marginal brim ornamented with dentated ribs. The visceral surface convex to concave, pierced by pores. Comparison. Kaimenella gen. n. resembles Hadimopanella in having phosphatized sclerites with tubercles and sculptured marginal brim. Characteristic of Kaimenella gen. $n$. is the arrangement of tubercles in subparallel rows, different pattern of sculpture of marginal brim and, most important, the high porosity of the visceral surface and the spongy internal structure.

Kaimenella reticulata sp. n.

Pl. III, figs. $1-6,8-10$, Pl. IV, figs. $4-6$

Holotype and type locality. Pi 7052 (Pl. III, fig. 2), Estonia, Turjekelder outcrop, Cambrian and Ordovician boundary beds, Kallavere Formation, Maardu Member.

Material. 30 specimens.

Diagnosis. The same as for genus.

Description. Morphology. The small phosphatic sclerites are oval (Pl. III, figs. 1,2 ) to strongly elongated (Pl. III, figs. 6,8 ) in outline, so that the length may exceed the width three times. Their maximum length is $0.25 \mathrm{~mm}$. Somewhat raised external surface is covered with convex or conical tubercles. Their number varies from 8 to 18 . The tubercles are placed in two subparallel or parallel rows. The terminal tubercles, as a rule, are smaller (Pl. III, figs. 4-8). A slight asymmetry of some sclerites and the difference in the number of their tubercles in both rows seem to indicate the presence of right and left elements (Pl. III, figs. 6,8 ). In a specimen (PI. III, fig. 4) the older tubercles are overgrown by the thorn-like younger ones. Quite characteristic are the furrows (P1. III, figs. $3,4,6,8$ ) and small pores (Pl. III, figs, 3,5 ) around the tubercles. The marginal brim occurs as a downstepped or downcurved area. The marginal brim of the holotype (Pl. III, fig. 2) is covered with longitudinal dentated ribs. As a rule, this sculpture is not preserved, and we can find 
shallow grooves and small pores on the marginal brim. The visceral surface is perforated (P1. III, fig. 10). The apertures of the cavities are diamond-shaped and arranged in regular diagonal pattern.

Histology. Sclerites of Kaimenella reticulata $\mathrm{sp}$. n. can be subdivided into 1) a lower reticular layer, 2) a middle spongy core and 3) an upper enamel-like layer. In the etched vertical longitudinal section of the sclerite it is visible that the base pore cavities are of an unequal depth (Pl. IV, fig. 6). The lamellar basal layer was not observable. Spongy core contains fine vertical canals and cavities with rough surfaces (Pl. III, fig. 9, Pl. IV, fig. 4). The upper surface of the sclerites is of the enamellike matrix (Pl. IV, fig 5) which is less subjected to the effect of $\mathrm{HCl}$ like Hadimopanella.

Associated fauna. Kaimenella reticulata gen. n. sp. n. occurs together with Hadimopanella collaris sp. n. (for other forms see p. 16).

\section{REFERENCES}

Bengtson, S. Early Cambrian button-shaped phosphatic microfossils from the Siberian Platform. - Palaeontology, 1977, 20, 751-762.

Berg-Madsen, V. Middle Cambrian biostratigraphy, fauna and facies in southern Baltoscandia. - Acta Univ. Upsal. Abstr. Upps. Diss. Fac. Sci., 1985, 781, 1-37.

van den Boogaard, M. The occurrence of Hadimopanella oezgueli in the Lancara Formation in NW Spain. - Proc. ned. Akad. Wet., 1983, B 86, 331-341.

Gedik, I. Orta Toroslar'da konodont biyostratigrafisi. - Bül. Türk. Jeol. Kurumu, 1977, $20,35-48$.

Gedik, I. Hadimopanella Gedik, 1977 'nin stratigrafik dagilimi ve mikroyapisi konusunda bazi gözlemler. - Karadeniz Tek. Univ. Yer Bilimleri Dergisi. Jeol., 1981, 1, N 2, 159-163.

Kaljo, D., Borovko, N., Heinsalu, H., Khazanovich, K., Mens, K., Popov, L., Sergeyeva, S., Sobolevskaya, R., Viira, V. The Cambrian-Ordovician boundary in the BalticLadoga clint area (North Estonia and Leningrad Region, USSR). - Proc. Acad. Sci. ESSR. Geol., 1986, 35, N 3, 97-108.

Müller, K.J. Milaculum n. g. ein phosphatisches Microphossil aus dem Altpaläozoicum. Paläont. Z., 1973, 47, N 3/4, 217-228.

Peel, J. S., Larsen, N. H. Hadimopanella apicata from the Lower Cambrian of western North Greenland. - Groenlands Geol. Unders. Bull., 1984, 121, 89-96.

Wrona, R., Early Cambrian phosphatic microfossils from southern Spitsbergen (Hornsund Region). - Palaeontol. Polonica, 1982, 43, 9-16. Academy of Sciences of the Estonian SSR,
Institute of Geology
Received

Dec. 24,1986

\section{Tiiu MÄRSS}

\section{VARAPALEOSOIKUMI HADIMOPANELLIIDID EESTIST JA KIRGIISIAST}

Artiklis on käsitletud kesk-kambriumi ning kambriumi ja ordoviitsiumi piirikihtide problemaatiliste organismide fosfaatseid skleriite. On kirjeldatud liike Hadimopanella oezgueli Gedik ja $H$. collaris sp. n. ning Kaimenella reticulata gen. n. sp. n., mis on paigutatud sugukonda Hadimopanellidae fam. $\mathrm{n}$.

\section{Tuйy МЯРСС}

\section{РАННЕПАЛЕОЗОИСКИЕ ХАДИМОПАНЕЛЛИДЫ ИЗ ЭСТОНИИ И КИРГИЗИИ}

Кембрнйские фосфатные скелетные элементы проблематичного организма Hadimopanella еще мало изучены. Они описаны до сих пор из Турции, Сибирской платформы, Шпицбергена, Гренландии, Испании и южной части Балтоскандии (см. список литературы). В статье рассмотрены два вида из Киргизии и Эстонин - Hadimopanella oezgueli Gedik и H. collaris sp. п. соответственно. Кроме того, нз Северной Эстонии описана новая форма Kaimenella reticulata gen. n. sp. n. Представители обоих родов объединены в семейство Hadimopanellidae fam. n. Хадимопанеллиды Эстонии происходят из пограничных кембрийско-ордовикских слоев. 